\title{
FORM AND MEANING: \\ MULTI-LAYERED BALANCED THOUGHT STRUCTURES \\ IN PSALM 24:4 \\ Rodney K. Duke
}

\begin{abstract}
Summary
The complex literary artistry of Psalm 24:4 reveals it to be the focal point of this song of procession to worship. Standing in a catechism-like section, this verse provides the answer to the question about those qualified to approach God. This text exemplifies how artistic form was used to set this verse apart, complement the content, and highlight its theological message. It employs four levels of balanced thought structures that emphasise the total purity that is expected from one who would draw close to God. Theologically this verse functions as a call to holiness in response to God's grace.
\end{abstract}

\section{Introduction}

\subsection{Purpose and Target Audiences}

The purpose of this paper is to identify how some of the poetic forms in Psalm 24, with particular emphasis on verse 4, provide insight into the psalm's meaning and enrich its theological message. ${ }^{1}$ Such formal structures do not function in isolation as abstract aesthetic entities. Rather, formal structures work symbiotically with content to create the full rhetorical impact, the 'meaning' of a text, including its aesthetic beauty. One must pay attention to form as much as to content, since function generally follows form. In this case, various poetic forms in

1 This article is dedicated to the honour of Dr Bruce K. Waltke, teacher, friend, and inspiration, who taught me to love the Psalms. A version of this paper, 'Multi-Layered Balanced Thought Structures in Psalm 24:4', was presented at the Biblical Criticism and Literary Criticism Section of the Annual Meeting of the Society of Biblical Literature, Washington, D.C., 19 November 2006. 
Psalm 24 provide insight into the psalm's thematic structure, as well as insight into the heart of its message. It is not new to biblical scholarship to look for formal features. Botha, for instance, also observed several of the features found in Psalm 24. ${ }^{2}$ The contributions of this paper either push such observations further or differ in terms of their function: by showing how specific formal elements of Psalm 24, particularly in verse 4 , work together to create a total rhetorical impact; by presenting the thesis that complex structures indicate a focal point of thought; by viewing changes in patterns as rhetorical section dividers, rather than as indicators of disunity; and by reflecting on some of the theological implications of this text. For the sake of clarity, the body of the paper is confined to an exposition that focuses on form and function, is written for a general audience, and may be read for continuity without referring to the notes. And, although it is not the purpose of this paper to resolve all issues of the psalm's origin, history of development or usage within Israelite worship, interaction with these issues, and with matters of translation take place in the footnotes for the more specialised audience.

\subsection{The Overarching Structure and Message of Psalm 24}

Psalm 24 is composed of three sections that create a rhetorical unity. ${ }^{3}$ Although there are a variety of opinions on the origin, historical development, and function(s) of Psalm 24, it lends itself to being viewed as some kind of liturgical processional song of entrance into

2 Philippus Jacobus Botha, 'Answers Disguised as Questions: Rhetoric and Reasoning in Psalm 24', OTE 22.3 (2009): 535-53.

3 The issue of compositional unity (see more at $n .11$ below) has been a subject of scholarly debate. Some scholars have proposed that the psalm is a compilation of two or three separate compositions. For example, C. A. Briggs saw Ps. 24 as a compilation of two psalms, the first in vv. 1-6 and the second in vv. 7-10 in C. A. Briggs and Emile G. Briggs, A Critical and Exegetical Commentary on the Book of Psalms (ICC; Edinburgh: T\&T Clark, 1906): 212-14; and Taylor saw three independent parts, vv. 12, 3-6, 7-10 in William Taylor, Psalms (12 vols.; vol. IV of IB; New York: Abingdon, 1955): 131. So, too, a recent commentator, John Goldingay, states, 'The psalm comprises three self-contained brief sections that are unusually unrelated to each other', in Psalms: Volume 1, Psalms 1-41 (Baker Commentary on the Old Testament), ed. Tremper Longman, III (Grand Rapids: Baker Academic, 2006): 356. Presenting a somewhat intermediate position between unity and disunity, Weiser also found three distinct sections, but concluded that they were to be interpreted as arising out of the same ritual setting, in Artur Weiser, The Psalms: A Commentary (OTL; Philadelphia: Westminster, 1962): 232. Still, whether the unity of this psalm was envisioned by an original author or by later redactors, one must suppose that the current form was meant to be comprehended as a whole. 
worship. ${ }^{4}$ The first section (vv. 1-2), employing creational motifs, ${ }^{5}$ opens the worship liturgy by proclaiming the sovereign ownership of the whole world by the Israelite God, YHWH. This proclamation occurs presumably as a procession prepares to make its way up the holy hill to YHWH's holy dwelling, quite possibly up Mount Zion to the Jerusalem temple (v. 3). This declaration reminds one not only of God's transcendent claims to own, and therefore to rule, the world that God has securely established; but it also leads to the reminder in the second section that this same God has graciously condescended to establish a covenantal relationship. That relationship is exemplified by the facts: a) that God has established a sacred dwelling space (v. 3); that is, a symbol of God's intimate presence and rule, in the midst of God's people, and b) that access requires a response of submission (vv. 3-6). Moreover, that same God, in the third section, acts as the glorious King (vv. 7-10) for the salvation of the people of God (v. 5). With the first section in mind, the people begin their procession to worship YHWH.

The second section (vv. 3-6) informs the members of the covenant community that they cannot take for granted their access to the holy

4 It is not the purpose of this paper to settle the debated issue of the original setting of Ps. 24 or its possible various functions over time, but rather to focus on how form and content work together. Various settings in life have been proposed for this psalm: a historical event (such as bringing the ark of the covenant into the temple), an annual ritual, a mythical celebration, and an eschatological foreshadowing. Still, the general common denominator, based on the psalm's motifs and structure, is that the setting was some kind of liturgical processional.

5 Creational motifs are significant because they signal YHwH's right to rule and continued rulership - the sovereign rule that is symbolically based in God's holy place (v. 3). 'To found' (yāsad, יָסָ ) is used where the creation is viewed as an erection of a building (Ps. 89:12; 104:5; Job 38:4). So, too, 'to establish' (cûn, כּ) is used as a close synonym (cf. Isa. 45:18; Ps. 8:4; 119:90; and the two verbs are used together in Prov. 3:19). Still, part of the concept here is not just the act of creating, but that God's creation is secure, because it is well founded and maintained. John Goldingay has emphasised the connection between creation in the abstract and the more concrete image of God's work providing security, because it is well built, in Goldingay, Psalms 1-41,357-58. 'Seas' and 'rivers' are common symbols of chaos, much like the 'watery deep' of Gen. 1:2, which YHWH overcomes as he sets boundaries between land and sea, and so demonstrates his sovereignty (cf. Ps. 29:10; 74:13-15; Isa. 43:2; Hab. 3:89). A God who can create and maintain such stability is to be reverenced and trusted (1 Sam. 2:8; Ps. 33:8-9; 1 Chr. 16:30). So, too, Craig C. Broyles sees the point not as merely God's ownership of the world, but highlighting God's dynamic victory over chaos in Psalms, ed. Robert L. Hubbard, Jr. and Robert K. Johnston (NIBCOT 11; Peabody, Massachusetts: Hendrickson, 1999): 128. See note on translation of line 2b. 
God. ${ }^{6}$ Rather, approaching and abiding in God's presence requires conforming to God's character. ${ }^{7}$ Verses 3-6 have a catechism-like structure of four parts: 1) a question, raising the challenge of who is worthy to enter the sacred space of YHWH (v. 3); 2) the answer, spelling out who is so qualified (v. 4);3) the resulting blessing received by those who are qualified (v. 5); and 4) the identification of such recipients as 'Jacob', another designation for Israel (v. 6) ${ }^{8}$. (Jacob/Israel [v. 6b] here has been limited in scope by the parallel identification as the 'generation seeking him' (v. 6a) to those who are faithful Israelites, since seeking is an act of submission and trust. ${ }^{9}$ )

The final section (vv. 7-10) appears to be a liturgical response by the worshippers inside and outside of the sacred place as YHWH symbolically enters with the procession. Since YHWH's presence was not to be represented by an image, but was represented by the ark of the covenant, it seems likely that the ark is in mind. Here again, the concepts of sacred presence and space are joined with the ideology of covenant relationship: the presence of the glorious King is associated

6 Religious cultures that have little sense of sacred space, may find it difficult to relate to Ps. 24; however, recapturing a sense of sacred space can enhance worship. Robert Alter notes that in Jewish tradition Ps. 24 is often sung as the Torah scroll, having been taken out of the ark, is carried around the congregation, in The Book of Psalms: A Translation and Commentary (New York: W. W. Norton \& Co., 2007): 83. I would suggest in analogy that in Christian tradition Ps. 24 might be used in preparation for any act of worship as a reminder of what it means to enter sacred space. For some examples of how the interpretation and use of Ps. 24 has developed in Christian tradition, see Allen Cabaniss, 'The Harrowing of Hell, Psalm 24, and Pliny the Younger: A Note', Vigiliae Christianae 7, no. 2 (1953): 65-74; Alan Cooper, "Ps 24:7-10: Mythology and Exegesis", JBL 102, no. 1 (1983): 40-41, esp. 55-60; and Marcel Poorthuis, 'King Solomon and Psalms 72 and 24 in the Debate between Jews and Christians', in Jewish and Christian Liturgy and Worship: New Insights Into Its History and Interaction, ed. Albert Gerhards and Clemens Leonhard (Jewish and Christian Perspectives Series; Leiden: Brill, 2007): 257-78, esp. 272-76.

7 Some theological traditions may find this claim disconcerting, as if the implication is that believers must achieve some state of righteousness that earns them a place in God's presence. For some reflection on this issue, see the final section, 'Theological Reflections'.

8 Weiser, who also understood the occasion of Ps. 24 to be a procession, referred to this section (vv. 3-6) as an 'Entrance Torah' that combines a trustful confidence of a believer in being able to enter into God's presence along with the weight of responsibility of unconditional obedience that God's character demands of the believer (Psalms, 233). A close parallel to these verses is found in Ps. 15, which opens with the question, 'YHWH, who may sojourn in your tent?' and then proceeds to describe the one so qualified. See, too, Isa. 33:14-16.

9 For similar associations in the Psalter with seeking God, see: Ps. 9:11; 34:10-12; 69:33-34; 77:3; 78:34; 119:10. 
with the fact that God is 'mighty in battle' on behalf of Israel. ${ }^{10}$ Through the poetic device of personification, the gates are directly addressed and commanded to open up for the entrance of YHWH, the glorious King, whose reign is both over creation (vv. 1-2) and over Israel as her Redeemer (v. 5).

In summary, although each section is thematically focused, the three parts flow together when one envisions a liturgical procession in which there is a proclamation, an entrance catechism, and the actual processional entry. ${ }^{11}$ Heard as a processional psalm of Israel, one hears the proclamation that the whole world belongs to God, that those who would draw near to him must be blameless, and that he, such a glorious and mighty King, is entering their gates. The three themes speak of God's dominion as Creator, of God's graceful offer of relationship (entering holy space) that calls for holy worshippers, and of God's powerful presence in the midst of the faithful. (See below the translation that is divided into sections and scanned to show balanced thought structures. Verse 4 will be treated separately.)

\section{Proclamation of YHWH's Ownership of the World}
1a)
A To YHWH [is]
B the earth
C and fullness of her,
1b)
$[\mathbf{A}]^{12}$
B the world
$\mathbf{C}$ and the dwellers in her;
2a)
A for $\mathrm{He}$
B upon the seas
C founded her
2b)
[A]
$\mathbf{B}$ and upon the waters ${ }^{13}$
C established her.

10 Although the war motifs in verses 7-10 may be troublesome to the community of faith, what should be noted is that war is not advocated here as a human pursuit, but rather as an act of God, who is responsible for delivering the righteous.

11 There are other arguments that support the conclusion that disparate sections were not brought together to from a unity, but that the composition as a whole was created as a unified piece. In an exposition of Gen. 1, John Walton shows that there is a common ancient Near Eastern concept of gods establishing their rule through creational acts and then taking up residence in the sacred space of a temple in which they 'rest' and from where they then rule, in The Lost World of Genesis One: Ancient Cosmology and the Origins Debate (Downers Grove: IVP Academic, 2009): 72-85. These are the same themes and order of themes in the three sections of Ps 24. Certainly the themes of YHWH as founder of the world (vv. 1-2) and as King (vv. 7-10) are elsewhere closely united in the psalms (Ps. 74:12-16; 89:9-18; 95:3-6; 149:2). So, too, Yair Mazor has argued for a well-integrated unity in terms of theme, structures, and ideology in 'Psalm 24: Sense and Sensibility in Biblical Composition', SJOT 7, no. 2 (1993): 303-16. For instance, Mazor argues that both vv. 3 and 6 serve pivotal roles by having themes that tie together the verses both preceding and following them (307-308, 310-11).

12 The sections separate each line into units of thought and the matching letters indicate that those two units have some sort of corresponding or balancing thought. 


\section{'Catechism' for Approaching Yhwh}

3a) A Who may ascend B to the mountain of YHWH

3b) A and who may stand B in the place of His holiness?

4a) [One] clean of hands

4b) and [one] pure of heart;

4c) Who does not lift up to falseness my/his soul, ${ }^{14}$

4d) and [who] does not swear to deceit.

5a)

5b)

6a)

6b)
A He receives

[A]
B blessing

B righteousness

A Such [is]

B The ones seeking Your face [are]
C from YHWH, C from the God of his salvation.

B the generation seeking Him.

13 נדָדרוֹת (n) here, since the English reader can see that it further specifies 'seas'. It does not, however, refer to specific rivers, but to the watery nature that surrounds and lies under the earth threatening its stability (e.g. Job 28:11; Ps. 74:15; 93:3). This verse is an allusion to God's creating and maintaining activities of bringing order to watery chaos (Gen. 1:2, 6-7, 9-10). Part of the imagery here is that, although the land seems perilously perched on underlying waters, God, the owner/founder of all, builds and maintains it to be secure.

14 This clause (4c) (אשר לא-נשא לשוא נפשי) is difficult to translate for two reasons. First, the idiom, 'lifting up $\mathrm{X}$ ' is used in a variety of ways. Second, within the Hebrew Masoretic textual tradition, there are two readings: the Leningrad text reads, 'does not lift up my soul/person', but the Cairo text and several other manuscripts and versions read, 'does not lift up his soul/person'. The difference is one letter in Hebrew, a waw versus a yodh, which can look quite similar. First, in regard to the idiom: when a person's 'soul' is 'lifted up' toward a non-personal object it usually means that one's desire is set on it (Prov. 19:18; Jer. 22:27; 44:14); but when the object is personal, the nuance is one of dependence (Ps. 25:1; 86:4; 143:8). Shāw' (שָׁ), 'falseness, emptiness, vanity', has a wide range of uses. For example, it may refer to behaviour that is ineffective or useless (Ps. 60:13; 127:2), or to speech that is lying or false (Exod. 23:1; Ps. 12:3; 41:7; 144:8), or to evoking God's name vainly (Exod. 20:7 = Deut. 5:11), or to what is worthless or false in the sense of idolatry, such as worthless gods (Ps. 31:7; Jer. 18:15; Jon. 2:9). Second, in regard to the variant reading: If the first person 'my' is correct, then YHWH is speaking, and the sense may be, 'one who is not false in dealings with me'. This idiom could be reminiscent of the commandment in Exod. 20:7 = Deut. 5:11, which seems to refer to a manipulative use of God. If the third-person reading of 'his' is correct, then the sense is probably, 'one who does not rely on what is false', probably in the sense of not relying on worthless gods/idols but rather relying on that which is substantial, YHWH, as in Ps 25:1. In either case the balance between $4 \mathrm{c}$ and $4 \mathrm{~d}$ would be one of inner relationship with God (4c) versus one of outer relationship with others (4d). My translation accepts the more likely reading to be 'his soul', since the awkward shift of speakers in the same catechism (v. 3 - third person, v. 4 - first person, v. 5-third person) would be disruptive. Therefore, I have taken the phrase in the third person and understand "not lift up his soul to falseness' to be describing one who is not grounded spiritually on that which is unreliable and false, such as on idols, but implies that person is depending on what is true and substantial, YHWH. 


\section{Entrance Liturgy}

7a)

7b)

7c)

8a)
A Lift up,

A and be lifted up,

C So that may enter
B O Gates, your heads ${ }^{16}$

B O Doors of everlasting

D the King of glory.

D Who is this King of glory?

15 Here is an instance of where noting the balanced thought structure aids translation. Many translations in the past, apparently missing the balanced thought structure in the MT, have had difficulty with the second half of this verse. For instance, AV reads, 'This is the generation of them that seek him, that seek thy face, O Jacob.' NASV is much better with, 'This is the generation of those who seek Him, Who seek Thy faceeven Jacob.' Often, though, translators have preferred the text of the Septuagint (e.g. CSB, NAB, NIV, NJB, NLT, RSV, and NRSV). The Septuagint, along with two Hebrew MSS and the Syriac, basically reads, 'ones seeking the face of the God of Jacob'. The reading of the MT should be preferred because it explains the Septuagint reading as an attempt to clarify the meaning of the text and to conform it to a typical construction, 'the God of Jacob' (e.g. Gen. 49:24; Exod. 3:6). However, such clarification is not necessary. Perhaps the shift from speaking about God (6a) to direct address (6b) appears awkward, but it is found in the Psalms (e.g. Ps. 27, 32, 33) and is natural in a liturgical setting; therefore, it is possible to retain 'Your face' without any internal contradiction. It is not likely that 'God' would have been omitted from the MT intentionally here. And, 'Jacob' makes sense, when one realises that it often stands for the nation of Israel (for examples of where the terms are used in parallel, see Num. 23:7;24:5; Ps. 14:7;135:4; Isa. 40:27; Jer. 46:27; Ezek. 39:25; Mic. 1:5). Moreover, when one sees the parallelism in the MT, the MT is actually the simpler reading. The first clause is a nominal clause, which in English requires adding a 'to be' verb, and has the sense, 'such ones (A) [are] the generation of those seeking him (B)'. The second line is also a nominal clause, and inverts the first pattern from A B to B A, having the sense, 'the ones seeking Your face (B) [are] Jacob/we ourselves (A)'. With this balanced structure, the unnamed 'such ones' in 6a (A) are specifically identified in $6 \mathrm{~b}(\mathrm{~A})$ as faithful Israel. Abraham Ibn Ezra (1156 CE) rejected the added words as well and basically rendered the line as 'that seek Thy face, even Jacob', understanding the sense to be 'they are truly the seed of Jacob', in Abraham Ibn Ezra's Commentary on the First Book of Psalms: Chapters 1-41 (repr., Brighton, MA: Academic Studies Press, 2009; tr. H. Norman Strickman): 184. The earliest English translation which correctly rendered the structure and meaning of v. 6, that I have found so far is in the work of J. A. Alexander, The Psalms: Translated and Explained (Vol 1; $6^{\text {th }}$ edn.; New York: Charles Scribner \& Co., 1868): 201. For a survey of the interpretations of this phrase, see Nic Tromp, who, not seeing the parallelism, prefers the reading in the Septuagint in 'Jacob in Psalm 24: Apposition, Aphaeresis or Apostrophe?' in Von Kanaan bis Kerala: Festschrift für Prof. Mag. Dr. Dr. J.P.M. Van Der Ploeg O.P. zur Vollendung des siebzigsten Lebensjahres am 4. Juli 1979: überreicht von Kollegen, Freunden und Schülern, ed. W. C. Delsman, J. T. Nelis, J. R. T. M. Peters, W. H. Ph. Römer, and A. S. van der Woude (Kevelaer: Verlag Butzon \& Bercker, 1982): 271-82. 16 There is a technical difficulty of the fact that city/temple gates did not open upwards. However, this is poetry, in which either personification has been used in reference to the gates, perhaps visualising them as a council of elders waiting with drooping heads for the return of its army, an image possibly coming from Canaanite mythology as suggested by Frank Moore Cross, in Canaanite Myth and Hebrew Epic: Essays in the History of the Religion of Israel (Cambridge, MA: Harvard University, 1973), 97-99; or, as Cooper ably defends, a metonymy of gates for the gatekeepers (one shouts at the gates to get the gatekeepers' attention) in 'Mythology', 43-49. 

8b)
E YHWH,
$8 \mathrm{c})$
E YHWH,
F powerful and mighty;
F mighty of battle!
9a) $\quad$ A Lift up,
9b)
B O Gates, your heads
9c)
10a)
10b)
C So that may enter
B O Doors of everlasting
D the King of glory.
10c)
D Who is this King of glory?
E YHWH
F of hosts;

\subsection{Balanced Thought Structures and Section Division ${ }^{17}$}

Besides the obvious change in theme from one section of the psalm to the next, there are also some structural clues as to where one section ends and another begins. As can be observed in the translation above, all of the verses in the first two sections, with the exception of verse 4, exhibit a two-part symmetry between their a lines and b lines. Again, except for verse 4 , each of the two lines balances each other, with the second line developing some element of the first line, generally moving to greater precision of thought. ${ }^{18}$ In the third section, not only are there three part-lines per verse, but the structures of verses 7-8 together are

17 Generally OT scholars have referred to the poetic parallels between two or more lines as 'parallelism'. For a couple of reasons, it is preferable to use the designation 'balanced thought structures'. First, when thinking in terms of 'parallels', it became somewhat commonplace among scholars to label the parallelism between lines with such generalisations as 'synonymous', 'antithetical', and 'building', when the relationships are often more sophisticated. Second, when one thinks simplistically of parallels, one often just looks for verbal repetition. In reality one often finds phrases, or units of thought, which have no single words that correspond to each other, but whose meanings still play off each other. Therefore, 'balanced thought structures' is a more helpful designation. For a general discussion of such 'parallelism' and other literary devices in the Psalms, see Willem A. VanGemeren, Psalms (vol. 5 of The Expositor's Bible Commentary: Revised Edition; eds. Tremper Longman, III and David E. Garland; 13 vols.; Grand Rapids: Zondervan, 2008): 48-56.

18 On parallelism of greater precision, see David J. A. Clines, 'The Parallelism of Greater Precision: Notes From Isaiah 40 for a Theory of Hebrew Poetry' in Directions in Biblical Hebrew Poetry, ed. Elaine R. Follis (Sheffield: JSOT Press, 1987). For a counter argument, see Landy, who claims that the parallelism is merely synonymous, with the second clause adding nothing of significance (Landy, 'Psalm 24', 281). Also, Denise Dombkowski Hopkins finds an opposite movement in v. 1, with 'earth' ( or whole cosmos with its heavenly beings, in 'Psalms 15 and 24: The Moral Individual in the Religious Life of Early Israel' (Ph.D. dissertation, Vanderbilt University, 1984): 149-63. However, neither of these arguments is convincing. Although the terms may be used quite closely, the latter term is often used more narrowly in connection with earthly inhabitants (cf. Ps. 96:13; 98:9; Isa. 14:21; 18:3; 24:4; 26:9,18; 34:1). 
closely followed by the structures in verses 9-10 creating a parallel between verses 7 and 9, and between 8 and 10 .

Examining the balanced thought structures of the lines in each section more closely, allows one to see that there are further patterns that help to indicate a transition from one section to the next. In the first section, the flow of thought follows the pattern A B C, [A] B C. As one moves to the next section, the thought pattern changes to $\mathrm{A} B$, A B in the first line (v. 3). Indeed, each verse in the second section has a distinct pattern, calling greater attention to this, the catechetical, section. Quite possibly a skilled oral/aural audience heard such changes in thought pattern that complemented the introduction of a new theme. In the third section, a new theme, the entrance liturgy, is introduced by a different, interlaced thought pattern. Not only is there repetition between verses 7 and 9 and 8 and 10, but there is also an overlapping effect created as the phrase 'King of Glory' in $7 \mathrm{c}$ and $9 \mathrm{c}$ is picked up by $8 \mathrm{a}$ and 10a. Indeed the question and answer structure, as also found in verses 3-4, invokes the drama of an antiphonal liturgy and leads the audience into exuberant worship.

It is sufficient to note here that not only does each verse exhibit a balanced thought structure; but also to note that the balanced pattern of each section is different. The result is that such changing patterns set apart one section from the other, rhetorically highlight thematic shifts, and may even emphasise a particular verse, as I argue in the following treatment of verse 4 .

\section{Form and Meaning in Verse 4}

\subsection{Exposition}

Although each verse employs some form of balanced thought structure, creating a poetic complementation of form and content, the thought structures of verse 4 are the most complex in the psalm. ${ }^{19}$ This rhetorical complexity highlights the role of this verse in the psalm, calling attention to the middle catechetical section and to this verse

19 Botha, in an excellent close reading of the literary features of Ps. 24 has also observed many of the features that are described in the following section (the oppositions, some of the merisms, and the chiasm, in 'Answers Disguised as Questions', 540-45. However, he does not reflect much on the rhetorical significance of these features, nor does he see how the complexity of v. 4 makes it the focal point. 
specifically as the focal point of the psalm. It is here that the follower of God is confronted with the fact that the privilege of drawing near to God is not to be taken lightly. God's holy character is such that God requires moral purity of the ones who would enter God's presence.

First, one should note (see chart below) that the balance between the two halves (lines $4 a$ and $4 b$ contrasted to lines $4 c$ and $4 d$ ) is one of opposition. The person who is qualified to enter into YHWH's sacred space must manifest the positive attributes of being clean of hands and pure of heart (4a and $4 \mathrm{~b}$ ). This person is also without the negative characteristics of lifting up one's soul to falseness or swearing to deceit ( $4 \mathrm{c}$ and $4 \mathrm{~d}$ ). That is, verse 4 states the same character description in terms of what a person should be like positively and in terms of what a person should not be like, in order to create a whole character portrait. Together these two opposite statements create a figure of speech called a merism. A merism expresses a totality by pairing opposite components (e.g. 'heaven and earth' equals the whole cosmos; 'day and night' equals all the time). ${ }^{20}$ As a result, this first structure creates a portrait of a worshipper of God who is expected to be totally pure: with certain positive traits and without certain negative traits. ${ }^{21}$

\section{4) Answer}

a)

$$
\text { נקי כפים }
$$

[One] clean of hands

b)

$$
\text { ובר-לבב }\left\{\begin{array}{l}
\text { the positive } \\
\text { perspective }
\end{array}\right.
$$

And [one] pure of heart,

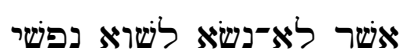

c) Who does not lift to falseness my/his soul,

$$
\text { ולא נשבע למרמה: }
$$

And [who] does not swear to deceit.

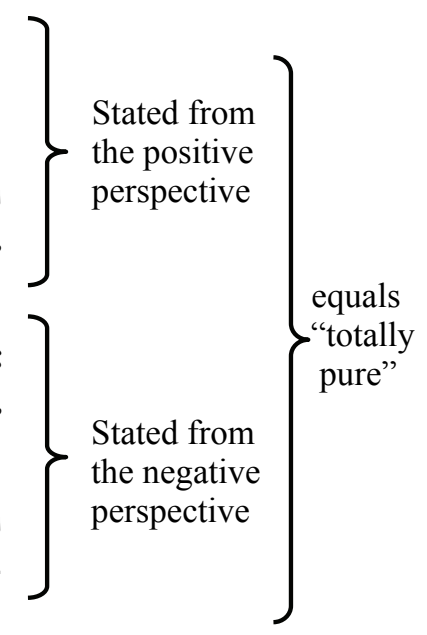

20 Goldingay, too, has noted the positive and negative statements; however, he misses the merism and its emphasis on completeness (Psalms 1-41,359).

21 One can find the same device of balancing opposites elsewhere, for example, see Prov. 20:13: 'Do not love sleep, lest you become poor; open your eyes, be sated with food.' 
Second, there is another merism created between the elements of $4 \mathrm{a}$ and $4 \mathrm{~b}$. A person who is 'clean of hands' (4a) is one who is outwardly pure. ${ }^{22}$ 'Hands' is frequently used as a metonymy for the deeds that one does. ${ }^{23}$ For instance, in Psalm 7:3 [Heb. v.4] 'guilt on my hands' is qualified as 'done evil' in the next verse. However, in contrast to 'clean hands', a person who is 'pure of heart' (4b) is inwardly pure. In Hebrew idiom, the heart stands for the inner person, the mind and will. ${ }^{24}$ The balance between $4 \mathrm{a}$ and $4 \mathrm{~b}$, therefore, again expresses the concept of total purity by complementing outward personal purity with inward purity. ${ }^{25}$ (See the illustration following the next paragraph.)

Third, there is another merism created by the components of $4 \mathrm{c}$ and $4 \mathrm{~d}$. To 'lift up one's soul to falseness' (4c) is an idiom for entrusting oneself to that which has no substance to it. ${ }^{26}$ The expression can be used of worshipping idols, since to worship an idol is to depend on that which is unsubstantial. The opposite action, which is implied by the negation, is to set one's soul upon YHWH, who is a substantial and firm foundation. The phrase 'to swear to deceit' completes the merism by expressing an outward behaviour that must be absent. A person swears, or takes an oath, in regard to personal relationships, as one would give one's word in a business transaction. ${ }^{27}$ The phrases in $4 \mathrm{c}$

22 The adjective 'clean' ( $n^{1} q \hat{\imath}$, פִִ $)$ is frequently used for 'blameless', and in Exod. 23:7 is used as a parallel term for 'righteous' (faddîq, צבְּדיק ). Here it has the nuance of being free from guilt before YнwH as in 2 Sam. 3:28.

23 See similar idioms employing 'hands' to refer to one's innocent or sinful actions: 1 Chr. 12:17 [Heb. v. 18]; Job 16:17; 22:30; 31:7; Ps. 7:3 [Heb. .v 4]; 26:6; 73:13; Isa. $59: 3,6)$.

24 The adjective 'pure' (bar, ר马), which can mean 'clean' (Prov. 14:4) is used figuratively for the moral quality of purity (e.g. Job 11:4; Ps. 19:9; 73:1), whereas 'heart'

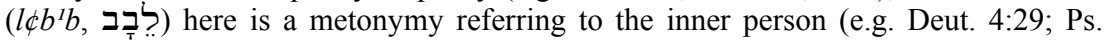
$73: 26)$.

25 A similar pairing of contrasting idioms using 'hands' and 'heart' to represent the whole person, outward and inward, may be found in Job 11:13; 31:7; Ps. 58:2; 73:13; 78:72. Konrad Schaefer, too, saw this merism as an expression embracing action and intent in Psalms (Berit Olam: Studies in Hebrew Narrative \& Poetry; Collegeville, MN: Liturgical Press, 2001): 60.

26 See note 13 above.

27 'Swear deceitfully' would be a better English idiomatic rendering. Mirmâ (מִרְדָה), 'deceit', is a characteristic of the wicked who oppress the righteous (Ps. 35:20; 36:4; $38: 13$ ) and is the opposite of what is true and just (Prov. 11:1; 12:5, 7). It is often something that is spoken by those who are wicked (Ps. 10:7; 34:14; 36:4). Swearing is an act of making a promise. The idiom here creates an adverbial force as in Lev. 5:22, in which 'to swear to deception' means 'to swear deceitfully'. The Septuagint makes

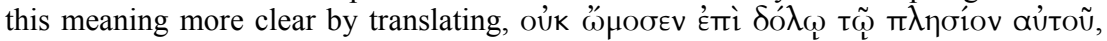
'does not swear with guile to his neighbour', probably relating it to Ps. 15:4. 
and $4 \mathrm{~d}$, therefore, emphasise the totality of the negative qualities that a person should be without in order to worship God, again formally presenting a picture of total purity. ${ }^{28}$

4) Answer

POSITIVE

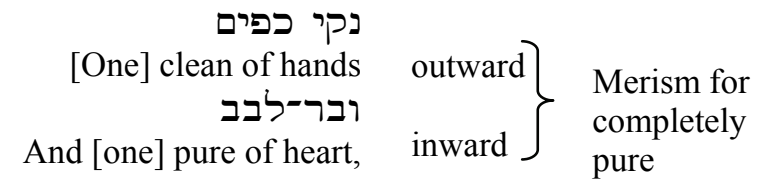

NEGATIVE

\section{אשר לא-נשא לשוא נפשי}

Who does not lift to falseness my/his soul, And [who] does not swear to deceit.

Finally, the four elements of these two merisms are arranged in a chiastic structure. A chiasm is an instance of inverted repetition. Whereas simple repetition will repeat elements in a linear pattern (AB $A B)$, chiastic repetition inverts the second sequence (AB BA). One impact of a chiastic structure, that of using the same element to open and close a sequence, is a sense of inclusion or completeness to a unit of thought. The chiastic structure created by the four components of verse 4 , creates a final pattern emphasising the total purity of the worshipper: A) outward positive character, B) inward positive character, B) inward negative character, and A) outward negative character. ${ }^{29}$ See the following illustration.

28 This literary device of two merisms complementing each other may be found as well in Ps. 113:2-3, in which they are also bracketed within the call to praise the name of YHWH.

29 The relationships between these balancing actions have been interpreted differently. Botha also saw this chiasm in terms of thought and action ("Answers Disguised as Questions', 541). Schaefer saw this structure as well, but does not clarify it. He seems to imply that the 'A' elements emphasised one's relationship with others versus the 'B' elements that speak of one's relationship with God (Schaefer, Psalms, 60). Goldingay, citing Schaefer, thinks that such an interpretation is 'too tight', since one's relationship with God influences one's relationship with others (Psalms 1-41, 359). However, both observations are important. Such poetic structures as chiasm are not meant to reduce the range of meaning of these phrases, but to allow the audience to hear/see various patterns of meaning. One should note that as the Decalogue brings together commands about right relationship with God and commands about right relationship with others, so, too, the psalmist here posits a complementary balance 


\section{4) Answer}

POSITIVE

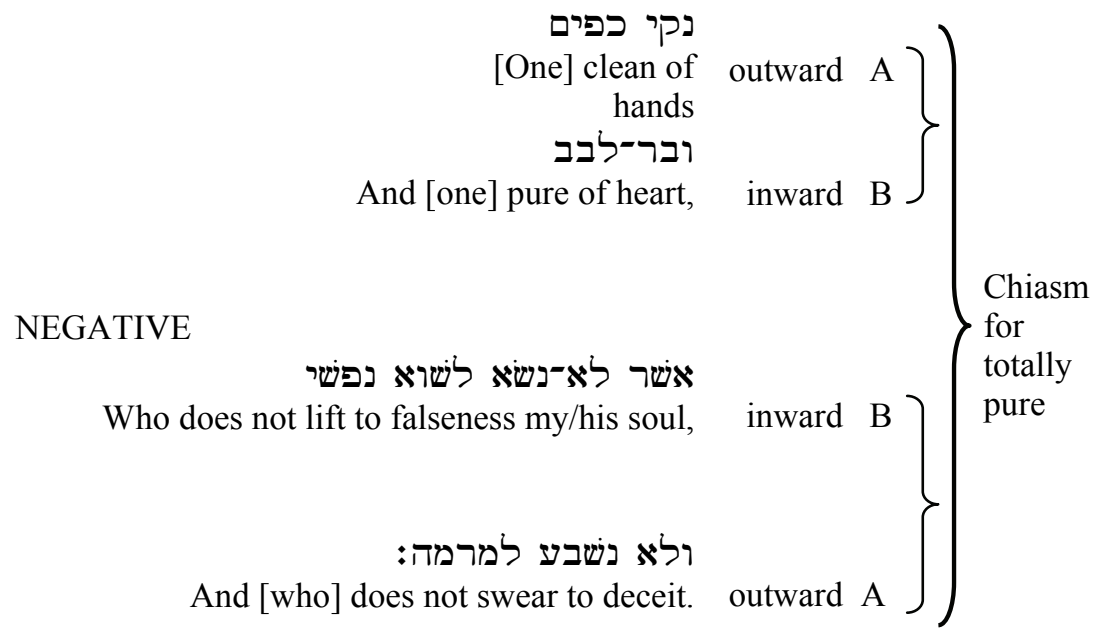

\subsection{Summary}

The biblical psalmists employed various artistic literary features of form in order to complement and enhance the message expressed by the content. In the case of Psalm 24, the second stanza, the catechism for entering divine space to worship God, first calls attention to itself by each verse having a different balanced thought structure, rather than a repeated pattern among its verses as the other sections do. Second, the fourth verse calls attention to itself as the most formally complex verse in the whole psalm. In this formal sense, it is the focal point of the psalm. This verse provides the answer to the catechistic question expressed in verse 3, 'Who may approach the sacred space of YHWH to worship Him?' The mere content level of this call to holiness is complemented and emphasised four ways on the formal level: 1) through a balance of positive and negative (lacking) character attributes, which together form a merism addressing the totality of character, 2) through two other merisms, each combining inward and outward aspects of character to emphasise total purity, and 3) through

between both those relationships. Accordingly, Steven S. Minter saw the same relationship in v. 4 that is found in the Decalogue. He also finds some possible allusions to the Decalogue: avoiding idolatry in the first and second commandments in Exod. 20:3-6 and false swearing in the third and ninth commands in Exod. 20:7 and 18 respectively, in 'The Qualifications for Worship in Psalms 15 and 24:3-6', (Th.M. dissertation; Dallas Theological Seminary, 1986): 56-58, 81. Hopkins also explores the moral nature of Ps. 24 in connection to the Decalogue ('Psalms 15 and 24', 260-321). 
the bracketing effect of a chiasm, also expressing completeness. As a result, great emphasis has been placed on the need for holiness and purity on the part of those who desire to come close to worship YHWH.

4) Answer

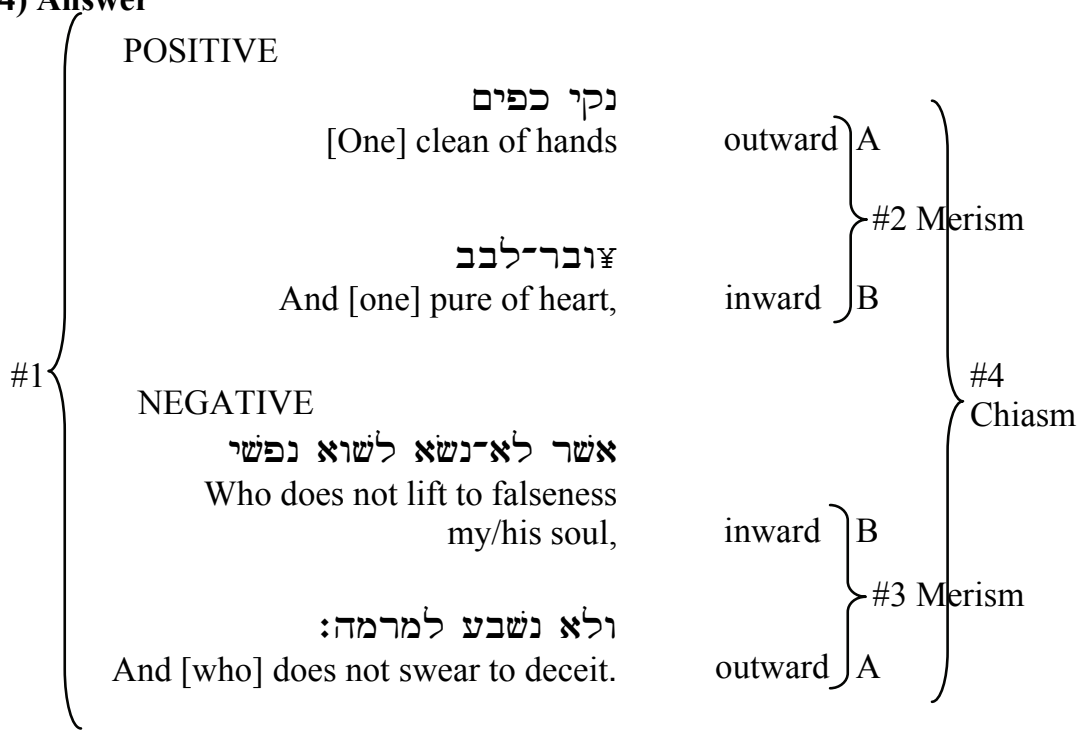

This particular psalm, with its uncompromising call to holiness, recognises that the inward and outward life are inextricably bound together, that a pure heart and a right relationship toward God (one not setting one's soul on that which is false) are bound together with righteous actions toward others. The message is clear: the person qualified to approach the sacred space is one who is to be absolutely, completely, and totally pure.

\section{Theological Reflections}

\subsection{Integrating Ethical and Ritual Behaviour}

Verse four and the catechistical section of Psalm 24 in general have particularly provoked theological questions for scholars who view the categories of ritual/worship, covenant/Law, and redemptive history as separate modes of expressing disparate Israelite theologies. For instance, representing a bifurcation between moral ethics and cultic ritual is Francis Landy, who posits that it is historically incorrect to relate ethical behaviour and sin with ritual behaviour and uncleanness. 
He sees verses 3-6 as a polemic against temple practice and wonders what a section like this is doing in a liturgical psalm. ${ }^{30}$ However, the precise point is that such a section is in a liturgical psalm and is about the ethical qualifications for entering sacred space, as one sees again in Psalm 15! One sees throughout the Hebrew Bible that the expression of relationship with YHWH in terms of access to divine presence and sacred space works symbiotically with other modes of expressing relationship with God. Maintaining proper relationship with God, as symbolised in terms of maintaining sacred space (ritual expression), is tied to obedience to the revealed will of God (legal and moral expression), and is interpreted by prophets and priests in terms of historical events (narrative expression). This is to say that the 'teachings' of ritual, Law, and redemptive history work together to guide the community of faith to perceive, maintain, and restore a proper relationship with God. One can see in Psalm 24 how a backgrounded narrative creational motif (vv. 1-2) is combined with the covenantal selection of sacred space in the midst of Israel (vv. 3 and 6), and an ethical/legal demand (v. 4) for entrance.

\subsection{Considering the Call to Purity}

Still, verse four and the catechistical section of Psalm 24 raise questions for the community of faith. What might the questions and response imply theologically? Did the Israelites actually see themselves as worthy of approaching YHWH and worthy of blessing? Botha, for instance, rightly recognises that the questions of verse 3 function rhetorically (in part) to move the audience to self reflection. ${ }^{31}$ After all, the inward attributes laid out in verse 4 could not be assessed by some priestly doorkeeper. Moreover, although the standard of purity seems to be incomparably high, the following verses affirm that such ones, those who seek YHWH (v. 6), do receive blessing and righteousness from YHWH (v. 5). Therefore, Botha is willing to see this section functioning as a word of encouragement, affirming the identity of a post-exilic community of Israelites/Judaeans as the ones who meet this

30 Francis Landy, 'From David to David: Psalm 24 and David Clines' in Reading From Right to Left: Essays on the Hebrew Bible in Honour of David J. A. Clines, ed. J. Cheryl Exum and H. G. M. Williamson (JSOTSup 373; Sheffield: Sheffield Academic Press, 2003): 275-89, esp. 283.

31 Botha, 'Answers Disguised as Questions', 535, 537, 545-47. 
standard, as the righteous ones. ${ }^{32} \mathrm{~A}$ closer look at the text, however, suggests a theology deeper than self affirmation of a select community.

The psalm reflects the grace of God, not human merit or communal self affirmation. It assumes that YHWH has already condescended to establish covenant relationship and to offer the closeness of God's presence as symbolised by the establishment of sacred space, 'His holy place' (v. 3). The catechistical section is intended for those who would avail themselves of the offer to worship the One to whom all creation belongs and to accept the offer to draw near to YHWH's presence. The unilateral grace of God is presupposed. Such an offer of intimate relationship is not achieved by human merit.

At the same time, in setting out the qualifications of those worthy to approach the 'glorious King', the psalm does not offer the believer the comfort of a standard that is humanly achievable. The standard is, as one would expect, one that conforms to the character of YHWH. The questions of verse 3 are rhetorical questions, which presuppose the answer, 'no one' for the following reasons. First, similar 'catechisms' can be found in Psalm 15 and Isaiah 33:14-16. In all three of these texts, rhetorical questions are asked about being in the presence of God (Ps. 15:1; 24:3; Isa. 33:14; see also Ps. 76:8 [Heb. v. 9]); however, the questions of Isa. 33:14 (Who of us can dwell with the consuming fire? Who of us can dwell with everlasting burning?) make quite clear what happens to ungodliness in the presence of God, and realistically expect the answer of 'no one'. ${ }^{33}$ Second, the questions are followed by standards of righteousness (Ps. 15:2-5a; 24:4; Isa. 33:15) that are not empirically measurable. And, third, those standards, particularly as emphasised by the interplay of rhetorical devices in Psalm 24:4, if truthfully assessed, do not fall in the range of human achievement. Yet each text goes on to affirm a resulting blessing of YHWH toward people as if the standards were achievable (Ps. 15:5b; 24:5-6; Isa. 33:16). How is this sensible? Are the standards merely hyperbole?

The solution to this dilemma again is the grace of God. The standards given in verse 4 are not open to empirically measurable tests

32 Botha, 'Answers Disguised as Questions', 535-37, 548-51.

33 So, too, Botha explores these other texts and argues that the answer to such questions is 'no one'. He, however, viewing Ps. 24 as a meditative poem, sees the questions in v. 3 as functioning rhetorically to honour YHWH, but ultimately to selfconfirm the religious community, to which the Psalms editors belong, as the true believers; that is, to give reassurance to themselves, 'Answers Disguised as Questions', 546-49. 
of merit. No one but God can see the purity of heart and how one's 'soul is set'. It is the divine standard set before the eyes of the faithful. That God responds with 'blessing' and 'righteousness', one must assume, is not because the standard has been met. Rather, as in verses $5-6$, one learns that the one who receives such blessing are the ones who seek the face of God. The blessed ones of verse 5 are not indiscriminately all Israel ('Jacob', v. 6), but are restricted to those who are seeking God. And, as noted above, 'seeking' is the opposite of self reliance. It is the humble attitude of reliance on the God who offers access to God's presence. Moreover, it is helpful first to recall that the Israelite historical literature is not boastful, political propaganda, but is self deprecating. Israelite literature does not claim self-merit for the covenant God made with Abraham and extended to the following generations. ${ }^{34}$ The community of faith constantly recognised that it fell short of its covenant commitment. Second, since Israelite sacrificial practice, including the Day of Atonement, addressed the need for forgiveness and for cleansing of Israelite pollution of the sacred space of God; and, since many psalms present petitions for mercy and forgiveness from God; it is therefore evident that the people of faith recognised that human failure was inevitable and could only be addressed efficaciously by the grace and mercy of God. One would hardly think that the psalmists behind Psalm 24 (and Psalm 15) to the contrary would make claims of such merit. Rather, one finds that both the call to total purity and the recognition of reliance on the grace and mercy of God for human failure belong together. ${ }^{35}$

As a result, one should conclude that a theological function of this catechistical stanza is to challenge the community of faith to respond to the grace of relationship offered by God with a sincere pursuit of holiness. The standard may never be achievable. Nevertheless, it is a standard to be taken seriously: as YHWH is holy, His worshippers are to be holy. Such is the standard that is found in Torah/Law, the

\footnotetext{
34 For a specific text, see Deut. 9:1-6; however, one only has to read Gen., Exod., Num., and Deut., Judg.-2 Kgs., and 1 Chr.-Erza-Neh. to see that this perspective is ubiquitous.

35 The subsequent call to holiness to maintain a proper relationship after the offer of grace, is found as well in New Testament teaching (e.g. Jesus' parable of the sheep and goats, Matt. 25:31-46; in Paul's teaching in Rom. 6:15-22; 1 Cor. 6:18-20; Eph. 4:2532; Phil. 2:12-16; Col. 1:21-23; 1 Thess. 4:1-8; in Heb. 10:19-29; and in 1 Pet. 1:142:3). Moreover, the standard of holiness (v. 4) is subsumed in Jesus' call to followers to be as perfect as God (Matt. 5:48).
} 
teaching of Jesus, and the proclamation of the early church (see respectively, Lev. 20:26; Matt. 5:48; 1 Cor. 1:2; Heb. 12:14; 1 Pet. 1:15-16). Nonetheless, those who stand in the grace of God, who desire to enter ever more closely into God's presence, those who seek God's face, are called to pursue lives of inward and outward purity. 